
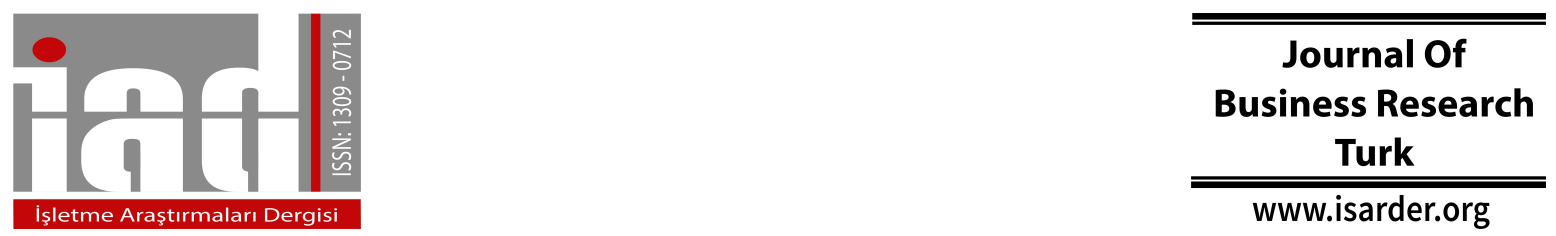

\title{
How Does Customer Experience Shape the Attitude Towards and Intention to Brand Switching?
}

\author{
Edin Güçlü SÖZER \\ Okan University \\ Faculty of Business and Administrative \\ Sciences, İstanbul, Turkey \\ orcid.org/0000-0003-4984-4629 \\ edin.sozer@okan.edu.tr
}

\author{
Mustafa Emre CIVELEK \\ İstanbul Commerce University \\ Faculty of Business \\ orcid.org/0000-0002-2847-5126 \\ ecivelek@ticaret.edu.tr
}

\begin{abstract}
Customer Experience (CeX) and Brand Switching Behavior (BsB) of customers play an important role in the market performance of brands. The underlying relationship between these two constructs to shed light into the success factors in the contemporary consumer markets. This study aimed to (1) explore the relationship between CeX and BsB behavior including Attitude Toward Switch (AtS) and Intention to Switch (ItS), (2) understand the effects of $\mathrm{CeX}$ on Customer Satisfaction (CuS), Brand Trust (BaT) and Brand Loyalty (BL), and (3) propose and test a sequential model of these relationships. The results of the study confirmed that positive $\mathrm{CeX}$ which has a statistically significant effect on $\mathrm{CuS}, \mathrm{BaT}$ and BL, eventually leads to the decreasing levels of AtS and ItS through the effect of BL. On the other hand, $\mathrm{CuS}$ and $\mathrm{BaT}$ are also found to be effective on BL. Finally, AtS is found to be effective on the ItS.
\end{abstract}

Keywords: Customer Experience, Brand Switching Behavior, Attitude Toward Switching, Intention to Switch.

\section{Introduction}

Today, business world intensively experiences the social and economic effects of the rapid transformation process, mainly boosted by technological advances, by being exposed to an increasing frequency of action-reaction circuit like a fast-evolving business karma. Three important dynamics, namely, disruptive innovation, neo-customers and social interaction, are the factors which force companies to adapt themselves into the new normal by leaving the conventional business models in order to survive in the market. 
In this post-digital era, hyper-connected consumers turned from need-oriented into want-oriented individuals and are characterized as demanding, less loyal and easily switching customers. This situation leads to the shorter duration of customer journeys with the brands which eventually causes to diminishing of loyal customer base and negative effects on the market performances of brands.

Brands need to implement a more holistic marketing approach in order to retain their customer base and prevent churn in this new market conditions. Successful brands in the post-digital era will be those which will adapt to the new dynamics in both strategical and tactical levels in order to create and sustain superior customer experience which is required for brands to be competitive in their markets.

As Customer Experience (CeX) and Brand Switching Behavior (BsB) of customers are the two important constructs which play an important role in the market performance of brands, both professionals and academicians need to explore the relationship between these two constructs in detail. In this perspective, this study aims to (1) explore the relationship between $\mathrm{CeX}$ and BsB behavior including Attitude Toward Switch (AtS) and Intention to Switch (ItS), (2) understand the effects of CeX on Customer Satisfaction (CuS), Brand Trust (BaT) and Brand Loyalty (BL), and (3) propose and test a sequential model of these relationships between the mentioned constructs.

This study is divided into the two sections: one is conceptual and the other is empirical. The explanation of conceptual background related to the $\mathrm{CeX}, \mathrm{CuS}, \mathrm{BaT}, \mathrm{BaL}$ and $\mathrm{BsB}$ constructs has been made and the presentation of conceptual background of the two constructs, conceptual research model has been introduced together with the hypothesis developed based on the findings of the previous studies in the current literature. Subsequent section contains the research methodology in detail covering measures and sampling methodologies, construct validity and validation checks and testing of hypothesis. In the final section, managerial implications, limitations of the study and suggestions for further research are presented.

\section{Conceptual Background}

\subsection{Customer Experience (CeX)}

The critical factor which brings a sustainable competitive advantage to companies in the market is their agility to implement a holistic approach to the marketing strategy by focusing on each stage of their customers' interaction with the company, its personnel, channels and products. Each interaction points of a customer with the elements of marketing programs implemented, together with each stage, which the customer goes from searching of the products to post-purchase evaluation, are the parts of the customer's journey with the brand, which in turn constitutes the basis and origin for the formation of the overall $\mathrm{CeX}$. The increasing weight of $\mathrm{CeX}$ approach in the strategic and tactical settings of companies created the need for academicians as well as professionals to define this construct and at the same time to explore its relationship with other marketing theory constructs in order to have a deeper understanding of its effects on market performance.

Whatever is the perspective of CeX construct such as customer, consumption, product, service or shopping oriented (Başer et al. 2015), it is defined in the current literature from a holistic perspective as a construct including sensory, affective, cognitive, 
physical and social dimensions (Verhoef et al. 2009; Schmitt, 1999). CeX is the result of positive customer perceptions (Ha and Perks, 2005) and it is originated via the direct and indirect interactions of customers with the brand (De Keyser et al. 2015).

In the light of the previous conceptualizations in the literature, Lemon and Verhoef (2016) defined CeX as "a multidimensional construct focusing on a customers' cognitive, emotional, behavioral, sensorial and social responses to a firms' offerings during the customers' entire purchase journey". The authors proposed the overall CeX model composed of five stages of customer journey including past experiences, pre-purchase stage, purchase stage, post-purchase stage and finally future experiences.

Since products and services offered in the market became commodities, CeX came ahead as the main differentiating factor for brands in the competition which eventually lead to the creation of economic value for the companies (Pine and Gilmore, 1998). Successful creation of CeX in a sustainable way creates a long term positive perception in consumers' memory (Carbone and Haeckel, 1994) which in turn results in positive outcomes for the brands in different contexts such as retailing (Grewal et al. 2009), business to business commerce (Biedenbach and Marell, 2010) and online shopping (Rose et al. 2012) environments.

\subsection{Customer Satisfaction (CuS)}

The new competitive landscape requires companies to adapt consumer centric strategies in order to be in compliance with the new dynamics and requirements of the contemporary markets. $\mathrm{CuS}$ has been regarded as one of the most important targets of customer centric business practices (Szymanski and Henard, 2001) and the management of customer satisfaction became an important strategic requirement for the companies (Mittal and Kamakura, 2001). Johnson and Fornell (1991) defined customer satisfaction as a "customers' overall evaluation of the performance of an offering to date" which is composed of transaction specific and cumulative (Boulding 1990). When customer makes a purchase, a post-transaction judgement leads to the transaction specific satisfaction level (Oliver, 1993). On the other hand, when customer has an accumulation of several experiences with the brand over a period, these lead to a more generalizable judgement of customer regarding the brand and it becomes an important indicator of future $\mathrm{CuS}$ (Fornell, 1992).

It is widely accepted by both professionals and academicians that $\mathrm{CuS}$ is effective in shaping the behavior of customers in a positive manner which in turn supports the companies to realize the strategic targets (Keiningham et al. 2003). Higher satisfaction leads to decreasing price elasticity of demand eventually making customers less resistant to price increases (Anderson, 1996) and accepting the prices offered more easily (Huber et al. 2001). Eventually this provides companies the opportunity to implement higher margins (Reichheld and Sasser, 1990). Satisfied customers have also higher propensity for involving into the positive word-of-mouth (Söderlund, 1998) and this increases future efficiency of advertising and promotion programs of companies (Luo and Homburg, 2007).

$\mathrm{CuS}$ is also effective in increasing the customer retention rate of companies which in turn contributes to the financial efficiency by positively affecting the Return on Investment (RoI) and Return on Assets (RoA) criteria (Anderson et al. 1994; Rust et al. 2002) and this 
eventually leads to the increasing financial performance (Chi and Gürsoy, 2009) as well as shareholder value (Anderson et al. 2004). The level of CuS is also affective on the firms' market performance and it is a tool for predicting future market shares of companies (Rego et al. 2013).

\subsection{Brand Trust (BaT)}

From psychology to economics and extending towards the management and marketing disciplines, the trust construct has been the focus of many academicians as well as professionals. As the marketing discipline evolved into a more holistic and relational approach over time, this concept, which involves the relational aspects of two parties, has become an important subject also in marketing literature (Ganesan, 1994). In a business context, trust is the perception of customers with respect to the firms' commitment to act in line with their interests based on shared values and objectives (Doney and Cannon, 1997). In this perspective, in order trust to be established and sustained between the firm and their customers over time, the former needs to develop required capabilities and capacities which will facilitate the accomplishment of firms' obligations as well as promises towards the customers. The ongoing value exchange between the company and customers and the accumulation of experience in this relationship is the main source of trust (Ravald and Grönroos, 1996).

Among the many definitions of $\mathrm{BaT}$ in the marketing literature, the definition provided by Delgado et al. (2003) as "the confident expectations of the brands' reliability and intentions" is one of the most explanatory of the construct from marketing perspective. The two dimensions, namely reliability and intentions, are the core components of this construct from marketing perspective (Ganesan, 1994). Reliability refers to the ability as well as willingness of the brand to create value for customers by accomplishing the obligations whereas intentions are related to the perception of customers with respect to the brands' positive intentions and efforts to support their interests and solve their problems during their relationship (Delgado-Ballester and Munueva-Aleman, 2005).

As the most critical factor for the establishment of long term customer relationships (Morgan and Hunt, 1994), a well-established BaT is a tool for customers to mitigate the perception of risks related to the purchases (Power et al. 2008). Customers with high BaT levels show higher propensity to repurchase both in offline (Zboja and Voorhees, 2006) and online (Kim et al. 2008) shopping context and they are less hesitant to accept brand extensions (Reast, 2005). All these positive outcomes of BaT on consumer behavior creates a positive association with the brand equity of the company (Delgado-Ballester and Munuera-Aleman, 2005) and indirectly supports market share of the companies (Chaudhuri and Holbrook, 2001).

\subsection{Brand Loyalty (BaL)}

Brand loyalty is characterized as being a psychological process resulted in a biased behavioral response towards a particular brand in a consistent way among the competing alternatives in the market (Jacoby and Kyner, 1973). A complete and effective BaL requires customers to show both behavioral and attitudinal loyalties at the same time. At one side, behavioral loyalty occurs when customers make a repeat purchase of the same brand (Blattberg and Sen, 1974). At the other side, strong commitment to re-purchase the brands' 
product or service in a continuous way in the future proves the attitudinal loyalty of customers towards a brand (Dick and Basu, 1994).

Current marketing literature lists the advantages of having a loyal customer base as providing a protecting shield for companies by preventing competitor firms entering into the market, reducing costs related to marketing practices, increasing the willingness of customers to pay more for the brand, and preventing the brand from the counter-actions of other players in the market (Aaker, 1991; Reichheld, 1996; Mellens et al. 1996). A loyal customer base contributes to the financial performance of the company's by increasing the profitability through customer retention (Hallowell, 1996) and it also helps to boost the market share by supporting the creation of strong customer based brand equity (Dodds et al. 1991).

\subsection{Brand Switching Behavior (BsB)}

The main motivation of consumers which lies behind choosing a brand is the value they get by involving into a relationship with the company. This relationship continues if both parties benefit from the outcomes of this relationship in parallel to their expectations. When customers prefer to continue their relationship for longer periods with the brand, they purchase more in volume with higher frequency and they are less resistant to price premiums (Reichheld and Kenny, 1990). These customers have also higher propensity to engage into the positive word-of-mouth and facilitate the acquisition of new customers for the brand which eventually leads to increasing market share (Heskett et al. 1997).

In cases where customers become unsatisfied with the relationship outcome, then the process of dissolution begins (Michalski, 2004). The most widely cited trigger event of BsB in marketing literature is the customers' dissatisfaction with the product or service performance (Keaveney, 1995; Kanwal and Lodhi, 2015). The perception of customers related to the economic outcome of the relationship such as price is also an important determinant of their intention to continue their relationship. If customers perceive the value for money they receive lower than the expected one, then they evaluate the price paid as unfair and their propensity to switch the brand increases (Bansal et al. 2005). The improvement of the relationship between the customer and the brand depends on the strength of the commitment showed by the brand's organization and this directly affects the satisfaction level and consequently the intention of customer to switch the brand (Hosseini and Amini, 2016). The strength of the effects which these triggering factors impose on BsB of customers are moderated by several factors including the involvement level of customer with the product (Shukla, 2004) and switching cost of customer to another brand (Burnham et al. 2003).

Any failure by the brand to retain the customers will result in customer churn which means the switching of customer to a competitor brand in the market. This will have important negative consequences for the market performance of the brand since it faces decreasing future cash flows and increasing advertising costs to replace the lost customer base (Keaveney, 1995).

In the light of the existing marketing literature and for the purpose of this study, the BsB has been split and integrated into the model in two dimensions, namely Attitude to Switch (AtS) (Gamble et al. 2009) and Intention to Switch (ItS) (Antón et al. 2007). 


\section{Research Model and Hypothesis Development}

The proposed research model in Figure 1 aims to test the effect of Customer Experience on Brand Switching Behaviour by exploring the relationship between Customer Experience, Customer Satisfaction, Brand Loyalty, Brand Trust, Attitude to Switch and Intention to Switch in a sequential order.

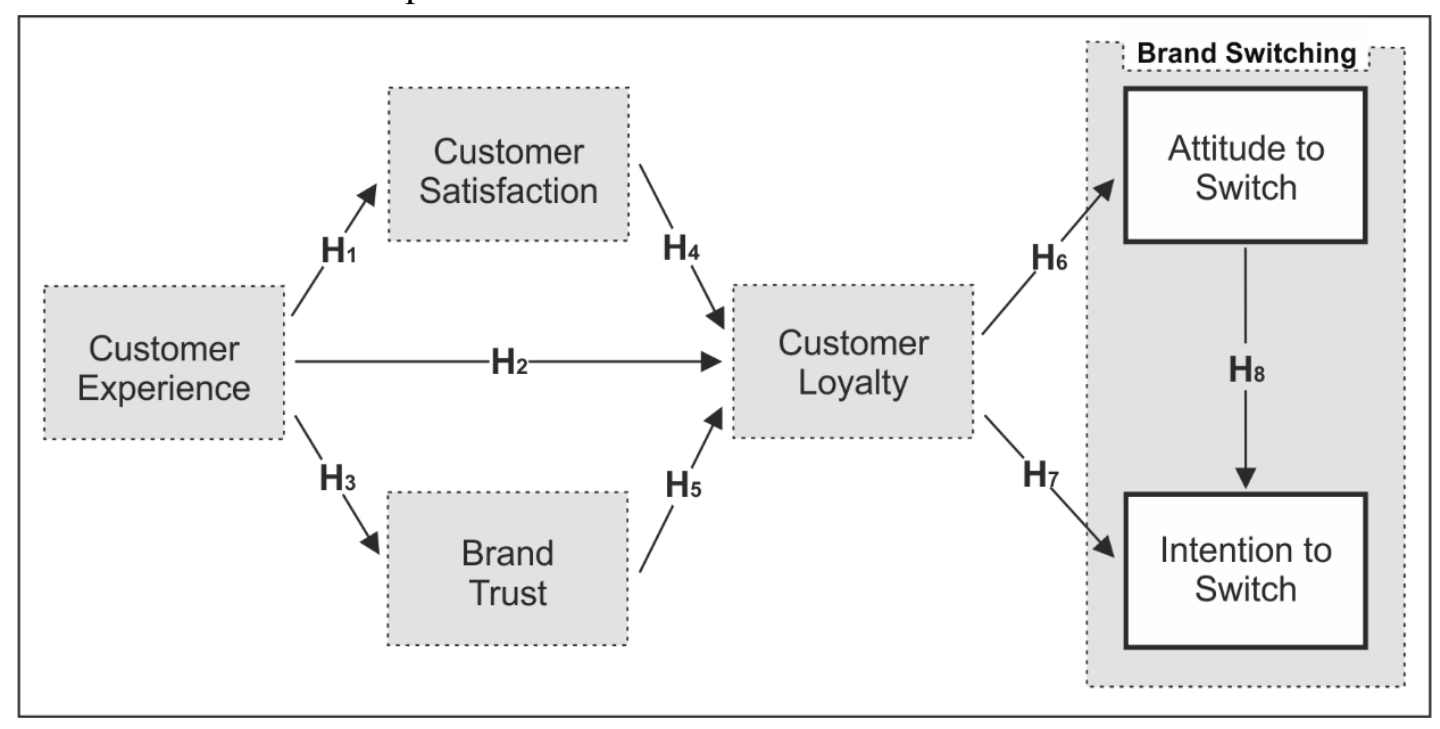

Figure 1. Conceptual Model

\subsection{The Relationship between $\mathrm{CeX}$ and $\mathrm{CuS}$}

The new normal of consumer expectations from their relationship with brands goes well beyond of a transactional nature, which includes a successful completion of a transaction, to a more holistic dimension which creates a total customer experience from end to end of the customer journey. The new dynamics of this relationship makes $\mathrm{CeX}$ as the most important pre-requisites of CuS. Brands need to deliver superior customer experience in order to satisfy their customers and protect themselves from competitor threats.

Studies in the literature confirm also the positive effect of $\mathrm{CeX}$ on $\mathrm{CuS}$ in different context and situations. In the business to business context, $\mathrm{CeX}$ has a strong impact on the overall satisfaction of customers (Venkat, 2007). Retail customers also have higher satisfaction levels when their $\mathrm{CeX}$ with the brand is in line with their expectations (Başer et al. 2015). Similarly, in the services context, CeX has a positive effect on CuS (Maklan and Klaus, 2011). Studies conducted on online consumer behavior also confirm the positive effects of CeX on the CuS in online shopping context (Rose et al. 2012). Thus, in the light of the existing marketing literature we hypothesize that:

$\mathbf{H}_{1}$ : Customer Experience (CeX) has a positive effect on Customer Satisfaction (CuS).

\subsection{The Relationship between $\mathrm{CeX}$ and BaT}

Another critical success factor in establishing long-term customer relationships which may lead to increasing financial and market performance is to create and sustain a strong trust of customers towards the brand. As the brand trust concept in marketing is borrowed from social psychology which studies personal relationships in its core (Delgado-Ballester 
and Munuera-Aleman, 2001), it requires recurring interactions of the brand with the customers to be established (Zhou et al. 2012). Thus, experiences of customers with the brand, which are the accumulation of these interactions, are the most critical antecedents for the creation of the brand trust (Wang and Emurian, 2005).

Marketing literature includes many studies which confirm the positive relationship between $\mathrm{CeX}$ and $\mathrm{BaT}$ in different contexts. In retail industry, positive $\mathrm{CeX}$ is found to be affective on BaT (Başer et al. 2015; Kim, 2005). Consumers in online shopping environment also have higher $\mathrm{BaT}$ when they have strong $\mathrm{CeX}$ with the brands $(\mathrm{Ha}$ and Perks, 2005; Janda and Ybarra, 2006). Thus, in the light of the existing marketing literature, we hypothesize that:

$\mathbf{H}_{2}$ : Customer Experience (CeX) has a positive effect on Brand Trust (BaT).

\subsection{The Relationship between $\mathrm{CeX}$ and BaL}

It is widely accepted by both professionals as well as scholars that establishing longterm customer relationships are the most critical pre-requisite of superior financial and market performance. Long-term customer relationships with customers to be established requires having a loyal customer base. Based on the new dynamics of the contemporary markets, having a loyal customer base requires to develop and sustain positive customer experiences throughout their journey with the brand.

Studies in the marketing literature, which explored the relationship between these two constructs, confirmed the effect of $\mathrm{CeX}$ on $\mathrm{BaL}$ in several contexts and situations. Iglesias et al. (2011) studied the relationship between $\mathrm{CeX}$ and $\mathrm{BaL}$ on several retail product categories and confirmed the positive effect of CeX on BaL. Similarly, Şahin et al. (2011) reported the positive effect of $\mathrm{CeX}$ on $\mathrm{BaL}$ in global retail brands setting. Parallel to the previous findings, $\mathrm{CeX}$ has found to be effective on $\mathrm{BaL}$ also in business-to-business services context (Biedenbach and Marell, 2010). Online shopping experience also found being an important contributor to the $\mathrm{BaL}$ by increasing online purchase intention of customers (Khalifa and Liu, 2007). Consequently, in the light of the existing literature, we hypothesize that:

$\mathbf{H}_{3}$ : Customer Experience (CeX) has a positive effect on Brand Loyalty (BaL).

\subsection{The Relationship between $\mathrm{CuS}$ and BaL}

Whatever is the country, industry or context which the brand operates in, it is a rule of thumb that customers are looking for their needs to be met by the offerings of the companies they work with. When the result of the value exchange equation is positive for the customers, which results into increasing satisfaction level with the brand, customers tend to continue their relationship with the brands by showing both behavioral as well as attitudinal loyalty.

The relationship between $\mathrm{CuS}$ and $\mathrm{BaL}$ is one of the most studied areas in marketing literature and many of these studies confirm the positive relationship between these two constructs. Awan and Rehman (2014) studied this relationship in durable goods sector and confirmed the positive effect of CuS on BaL. Similarly, Bloemer and Ruyter (1998) confirm the same positive effect of $\mathrm{CuS}$ on $\mathrm{BaL}$ in retail store context. In the services industry, $\mathrm{CuS}$ has found to be effective determinant of $\mathrm{BaL}$ in both business-to-business and business-to-consumer context (Lam et al. 2004; Msallam, 2015; Hallowell, 1996; Mc 
Alexander et al. 2003). Finally, e-satisfaction is also found to be positively effective in the e-store loyalty (Anderson and Srinivasan, 2003; Harris and Goode, 2004). Thus, in the light of the existing marketing literature, we hypothesize that:

$\mathbf{H}_{4}$ : Customer Satisfaction $(\mathrm{CuS})$ has a positive effect on Brand Loyalty (BaL).

\subsection{The Relationship between BaT and BaL}

One of the most leading characteristics of consumers in contemporary consumer markets is their search for authenticity and sincerity which leads to the formation of trust. For customer to engage into long lasting relations with brands, the formation of trust is one of the primary requirements. Professionals and scholars agree that customers who trust the brands they engage into an exchange relationship, tend to be loyal to these brands.

Studies in the marketing literature which aimed to explore this relationship also confirm the positive effect of $\mathrm{BaT}$ on $\mathrm{BaL}$ in different contexts. Retail customers who trust to the brand they prefer, tend to show both behavioral and attitudinal loyalty (Chaudhuri and Holbrook, 2001; Delgado Ballester and Munuera-Aleman, 2005). In the retail services industry, the trust of consumers to the brand positively affects the loyalty level of customers to the service provider (Lewis and Sourelli, 2006). BaT is also found to positively contribute to the BaL levels in the business-to-business services context by affecting the formation of loyalty related attributes (Chumpitaz and Paparoidamis 2007). Consumers who engage with brands in online environments tend to have higher level of store loyalty in cases where they trust to brands they prefer (Harris and Goode, 2004; Ribbink et al. 2004). Consequently, in the light of the existing literature, we hypothesize that:

H5: $_{5}$ Brand Trust (BaT) has a positive effect on Brand Loyalty (BaL).

\subsection{The Relationship between $\mathrm{BaL}$ and $\mathrm{BsB}$}

Contemporary markets have been characterized with extreme competition due to the high propensity of customers to switch their brands unless they have emotional bounds with the brands they prefer. The emotional aspect of the relationship is the most critical aspect of creating a loyal customer base which eventually leads both behavioral (Blattberg and Sen, 1974) as well as attitudinal loyalty (Dick and Basu, 1994).

Positive experiences of customers with the brands result in their intention to continue to purchase the brand in the future (Lubis et al. 2015) and this leads to a lower propensity for switching the brand since customers do not want to be exposed to additional search costs (Reichheld and Sasser, 1990). Customers who show strong brand loyalty tend to have smaller sizes of consideration sets and these customers show more willingness to make their purchases from the same brands (Sambandam and Kenneth, 1995). Thus, in the light of the existing literature, we hypothesize that:

$\mathbf{H}_{6}$ : Brand Loyalty $(\mathrm{BaL})$ has a negative effect on Attitude to Switch (AtS).

$\mathbf{H}_{7}$ : Brand Loyalty $(\mathrm{BaL})$ has a negative effect on Intention to Switch (ItS).

\subsection{The Relationship between AtS and ItS}

As one of the main studying areas of social psychology, the relationship between attitude and intention, has been also the subject of investigation in the marketing literature, especially after the evolution of marketing to a more relational perspective. From the 
perspectives of the theory of planned action and expectancy value model, attitudes eventually lead to behavioral outcomes based on the beliefs inherent in the memory (Ajzen and Fishbein, 2000).

The relationship between attitude and actual behavior has been the subject of many studies in marketing literature. Positive attitudes of customers toward the brand are found to be effective on their intention to make recurring purchases from the same brand (Baldinger and Rubinson, 1996). In the retail stores context, the behavioral intention of customers is mainly predicted by their attitude towards the store brands (Guerrero et al. 2000). The positive effect of attitudes toward an object on intention is also valid in eshopping context where positive attitude of consumers towards e-shopping influences their intention to shop online (Ha et al. 2009). The findings in different contexts and situations shows a strong relationship between attitude towards an object and the corresponding intention. Thus, in the light of the existing literature, we hypothesize that:

H8: Attitude toward the Switch (AtS) has a positive effect on Intention to Switch (ItS).

\section{Research Methods}

In this research, quantitative data was collected by using survey which was designed in five-point Likert and semantic scales. The scales employed in this research were taken from corresponding literature. In order to determine the validity and the reliability of these scales, confirmatory factor analysis (CFA) and reliability analysis were conducted respectively (Civelek, 2018). Subsequently, the hypotheses which were put forward in conceptual model were tested by structural Equation Modelling (SEM) method. This method is a multi-variable statistical method (Byrne, 2010). Conceptual model of this research contains direct and indirect relationships among the variables. Therefore, SEM was chosen as analysis method for eliminating measurement errors (Meydan \& Şeşen, 2011). All of the analysis was conducted in AMOS and SPSS statistics programs.

\subsection{Measures and Sampling}

The scales adopted from prior studies were used to measure the constructs. Customer Experience scale with 12 items (Brakus et al. 2008), Customer Satisfaction scale with 6 items (Oliver, 1980), Brand Trust scale with 8 items (Delgado-Ballester et. al. 2003) and Brand Loyalty scale with 3 items (Yoo \& Donthu, 2001) was adopted from previous studies in the marketing literature and Five-point Likert scale ranging from strongly disagree to strongly agree was used in their measurement. Attitude to Intention scale was adopted from Bansal and Taylor (2002) who operationalized 7 of 12 bipolar adjective items generated by Ajzen and Driver (1992). Similarly, Intention to Switch scale adopted also from the study of Bansal and Taylor (2002) who generated the 3 bipolar items from the studies of Oliver and Swan (1989) and Zeithaml et al. (1996). More than 750 distributed, 565 valid questionnaires were gathered from prominent cities throughout Turkey.

\subsection{Construct Validity and Reliability}

30 items were included in the confirmatory factor analysis after the data purification. CFA was performed so as to determine the construct validity (Anderson \& Gerbing, 1988). CFA results indicated that the fit indices of the model were in adequate level: $\chi 2 / \mathrm{DF}=1835$, $\mathrm{CFI}=0.893$, IFI $=0.895, \mathrm{RMSEA}=0.073$. $\mathrm{CMIN}$ is The Likelihood Ratio Chi-Square Test. Analysis indicate the conformity between the initial model and acquired model. A 
CMIN/DF ratio is below the threshold level of 3. Furthermore, other fit indices reached the acceptable level (Bagozzi \& Yi, 1990).

As shown in Table 1, standardized factor loads of each item are larger than 0.5 and significant according to the results of CFA. Additionally, average variance extracted values were calculated. Results are beyond the threshold level of 0.5 except one value (Byrne, 2010). These results indicate existence of the convergent validity of the scales. To evaluate discriminant validity, the square roots of AVE values of each variable were also calculated. The diagonals demonstrate the square root of AVE values in Table 2. Composite reliability and Cronbach $\alpha$ values are shown in Table 2. These values are beyond the threshold level (i.e. 0.7) (Fornell \& Larcker, 1981). Construct Correlation, average variance extracted values, composite reliabilities and Cronbach $\alpha$ values of each constructs are shown in Table 2.

Table 1. Confirmatory Factor Analysis Results

\begin{tabular}{|c|c|c|c|}
\hline Variables & Items & $\begin{array}{l}\text { Standardized } \\
\text { Factor Loads }\end{array}$ & $\begin{array}{l}\text { Unstandardized } \\
\text { Factor Loads }\end{array}$ \\
\hline \multirow{7}{*}{ Attitude to Switch } & ASWT31 & 0.684 & 1 \\
\hline & ASWT37 & 0.763 & 1.285 \\
\hline & ASWT33 & 0.783 & 1.172 \\
\hline & ASWT35 & 0.866 & 1.445 \\
\hline & ASWT32 & 0.839 & 1.355 \\
\hline & ASWT36 & 0.888 & 1.494 \\
\hline & ASWT34 & 0.880 & 1.405 \\
\hline \multirow{5}{*}{ Customer Satisfaction } & CSTF22 & 0.823 & 1 \\
\hline & CSTF24 & 0.898 & 1.115 \\
\hline & CSTF26 & 0.943 & 1.210 \\
\hline & CSTF27 & 0.628 & 0.900 \\
\hline & CSTF25 & 0.716 & 0.987 \\
\hline \multirow{8}{*}{ Customer Experience } & CEXP07 & 0.594 & 1 \\
\hline & CEXP05 & 0.580 & 0.971 \\
\hline & CEXP02 & 0.746 & 1.150 \\
\hline & CEXP03 & 0.806 & 1.399 \\
\hline & CEXP04 & 0.696 & 1.178 \\
\hline & CEXP08 & 0.553 & 1.019 \\
\hline & CEXP09 & 0.519 & 0.872 \\
\hline & CEXP10 & 0.537 & 0.945 \\
\hline \multirow{4}{*}{ Brand Trust } & BTRS21 & 0.514 & 1 \\
\hline & BTRS20 & 0.621 & 1.177 \\
\hline & BTRS19 & 0.784 & 1.362 \\
\hline & BTRS18 & 0.877 & 1.454 \\
\hline \multirow{3}{*}{ Customer Loyalty } & CLYT29 & 0.794 & 1 \\
\hline & CLYT28 & 0.694 & 0.869 \\
\hline & CLYT30 & 0.765 & 0.925 \\
\hline \multirow{3}{*}{ Intention to Switch } & ISWT38 & 0.798 & 1 \\
\hline & ISWT40 & 0.878 & 0.894 \\
\hline & ISWT39 & 0.868 & 1.053 \\
\hline
\end{tabular}

$\mathrm{p}<0.01$ for all items 
E. G. Sözer - M. E. Civelek 10/1 (2018) 856-875

Table 2. Construct Correlation, AVE and Reliability

\begin{tabular}{|c|c|c|c|c|c|c|}
\hline Variables & 1 & 2 & 3 & 4 & 5 & 6 \\
\hline $\begin{array}{l}\text { 1.Attitude to } \\
\text { Switch }\end{array}$ & (.807) & & & & & \\
\hline $\begin{array}{l}\text { 2.Customer } \\
\text { Satisfaction }\end{array}$ & -.119 & $(.810)$ & & & & \\
\hline $\begin{array}{l}\text { 3.Customer } \\
\text { Experience }\end{array}$ & -.148 & $.430^{*}$ & $(.649)$ & & & \\
\hline $\begin{array}{l}\text { 4.Brand } \\
\text { Trust }\end{array}$ & $-.187^{*}$ & $.498^{*}$ & $.510^{*}$ & $(.712)$ & & \\
\hline $\begin{array}{l}\text { 5.Customer } \\
\text { Loyalty }\end{array}$ & $-.311 *$ & $.424^{*}$ & $.452 *$ & $.466^{*}$ & $(.752)$ & \\
\hline $\begin{array}{l}\text { 6. Intention } \\
\text { to Switch }\end{array}$ & $.595^{*}$ & $-.210 *$ & $-.282 *$ & $-.315^{*}$ & $-.428 *$ & $(.848)$ \\
\hline $\begin{array}{l}\text { Composite } \\
\text { reliability }\end{array}$ & .917 & .903 & .833 & .799 & .796 & .885 \\
\hline $\begin{array}{l}\text { Average } \\
\text { variance ext. }\end{array}$ & .651 & .656 & .422 & .508 & .566 & .720 \\
\hline Cronbach $\alpha$ & .929 & .909 & .851 & .784 & .773 & .876 \\
\hline
\end{tabular}

$* \mathrm{p}<0.05$

Note: Diagonals show the square root of AVEs

\subsection{Test of Hypotheses}

In order to test the hypotheses, structural regression model was analyzed by using maximum likelihood estimation methods. Evaluation of the structural regression model was made according to the goodness of fit indices. The $\chi 2$ statistic and the root mean square error of approximation (RMSEA) are the absolute goodness of fit indices. The comparative fit index (CFI) and the incremental fit index (IFI) are the relative goodness of fit indices (Akgün, et al. 2014). As shown in Figure 2, goodness of fit indices indicates that model adequately fitted. $\chi 2 / \mathrm{DF}$ value is 1.687 and under threshold levels (i.e. 3). CFI is 0.900 , IFI is 0.902. RMSEA is 0.067. These values are satisfactory. As shown in Table 3, all hypotheses have been accepted. 
E. G. Sözer - M. E. Civelek 10/1 (2018) 856-875

Figure 2. Results of SEM Analysis

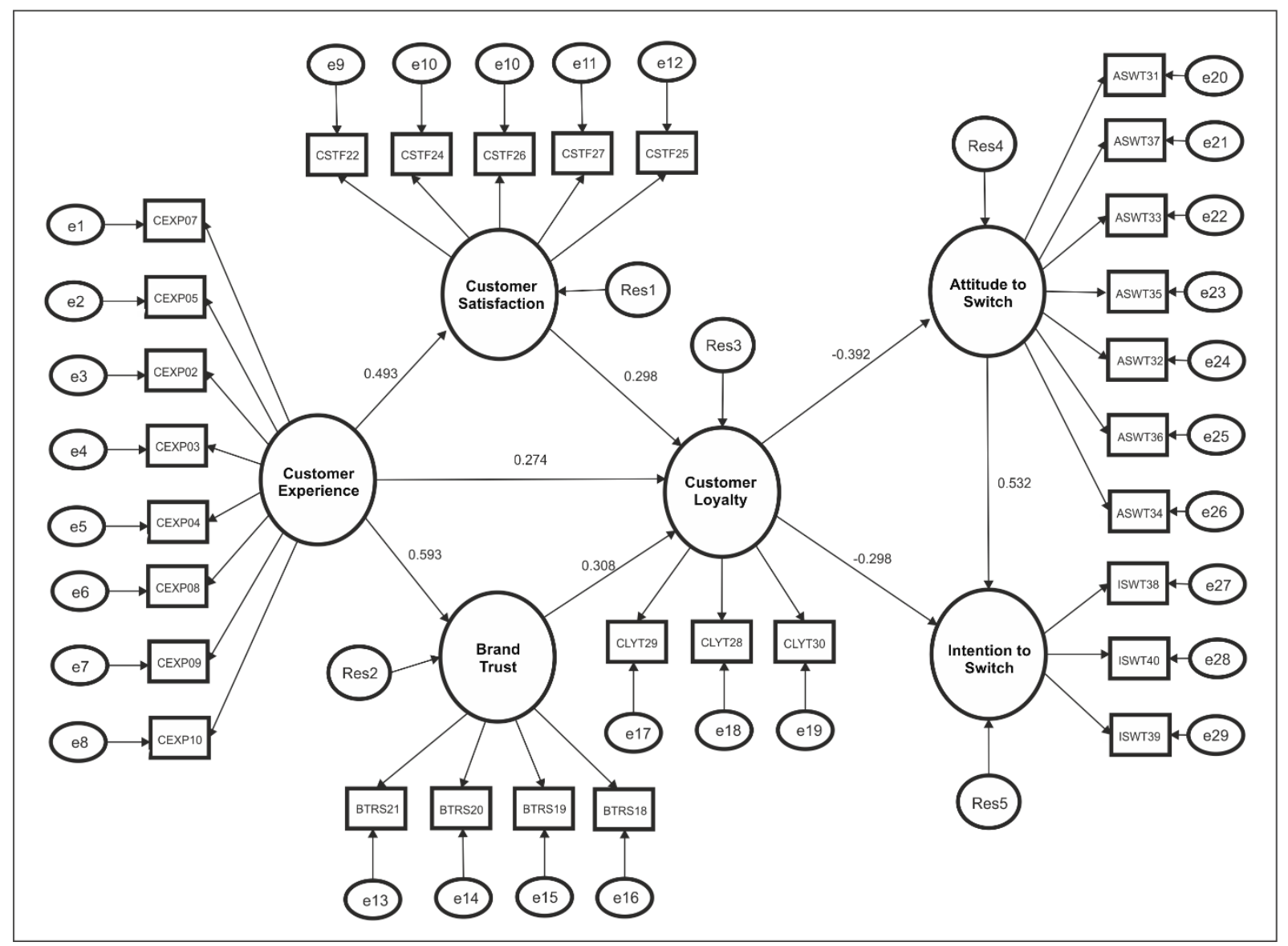

Note: $\chi 2 / \mathrm{DF}=1.687, \mathrm{CFI}=0.900, \mathrm{IFI}=0.902, \mathrm{RMSEA}=0.067$

Table 3. Hypotheses test results

\begin{tabular}{lcc}
\hline Relationships & $\begin{array}{c}\text { Standardized } \\
\text { Coefficients }\end{array}$ & $\begin{array}{c}\text { Unstandardized } \\
\text { Coefficients }\end{array}$ \\
\hline Customer Experience $\rightarrow$ Customer Satisfaction & $0.493^{*}$ & $0.581^{*}$ \\
Customer Experience $\rightarrow$ Brand Trust & $0.593^{*}$ & $0.516^{*}$ \\
Customer Experience $\rightarrow$ Customer Loyalty & $0.274^{*}$ & $0.382^{*}$ \\
Customer Satisfaction $\rightarrow$ Customer Loyalty & $0.298^{*}$ & $0.353^{*}$ \\
Brand Trust $\rightarrow$ Customer Loyalty & $0.308^{*}$ & $0.493^{*}$ \\
Customer Loyalty $\rightarrow$ Attitude to Switch & $-0.392^{*}$ & $-0.519^{*}$ \\
Customer Loyalty $\rightarrow$ Intention to Switch & $-0.298^{*}$ & $-0.376^{*}$ \\
Attitude to Switch $\rightarrow$ Intention to Switch & $0.532^{*}$ & $0.507^{*}$ \\
\hline
\end{tabular}

$* p<0.05$ 
E. G. Sözer - M. E. Civelek 10/1 (2018) 856-875

\section{Discussion}

\subsection{Findings and Managerial Implications}

This study aimed to contribute to the marketing literature by exploring the relationship between Customer Experience and Customer Switching Behavior which both play crucial role in financial as well as market performances of companies. The research model proposed and tested included Customer Experience, Customer Satisfaction, Brand Trust, Brand Loyalty, Attitude to Switch and Intention to Switch as the interacting variables in a sequential order. Parallel to the findings in the existing literature, results of this study confirmed the positive effect of Brand Experience on Customer Satisfaction (Maklan and Klas, 2011; Venkat, 2007), on Brand Trust (Kim 2005; Ha and Perks, 2005), and on Brand Loyalty (Iglesias et al. 2011). Furthermore, Brand Experience effect on Brand Loyalty, leads eventually to the decreasing levels of Attitude to Switch and Intention to Switch. On the other hand, results also confirm the findings in the literature regarding the effect of Customer Satisfaction (Rahman, 2014; Lam et al. 2004) and Brand Trust (Lewis and Sourelli, 2006; Rihhink et al. 2004) on Brand Loyalty. Finally, Attitude to Switch is found to be effective on the Intention to Switch of consumers to another brand which confirms the existing findings in the literature ((Baldinger and Rubinson, 1996). The results confirm the sequential model of these relationships which leads Customer Experience to eventually decrease the brand switching intention of customers.

The results lead to several managerial implications which need to be addressed in detail. First of all, taking into consideration the new dynamics of the consumer markets, results of the study confirmed that positive customer experience is the starting point and a precedent of strong loyal customer base, since it directly and indirectly (through customer satisfaction and brand trust) enhances the loyalty level of customers. Creating a unique, superior customer experience in a continuous way in order to have a sustainable competitive advantage in the market, companies need to implement a strategic approach supported by the tactical level actions.

In the strategic level there are some important pre-conditions which are required to be met in order to be able to deliver the superior customer experience in the tactical level. These pre-conditions are the development of a customer-centric organizational culture, down-to-top organizational structure and implementation of customer insight systems into the business processes. Customer-centric organizational culture will provide all business units to bring customer at the center of their business processes and will support the creation of superior value for the customer with the collaboration between the organizational units under one shared headline objective. Delivering superior customer experience needs to establish a down-to-top organizational structure which clears the way for getting customer feedback in a continuous way as the main source of designing a positive customer experience throughout the journey of customers with the brand. While establishing the required infrastructure in order receive continuous customer feedback which will feed the strategy formulation at the top of the organization is a good start, this customer feedback and information needs to be analyzed and turned into useful insights to be the core fuel of strategic formulation. At this point, companies need to develop customer insight systems in the organization in order to transform customer feedback and behavioral data gathered from each interaction of customer with the brand into useful insights. 
Brands which effectively satisfy the strategic level requirements of creating a unique and superior customer experience in a sustainable way, will benefit from the creation of satisfied customers with high brand trust as well as loyalty which in turn will support the retention of customer base and reduce the intentions of customers to switch to another brand.

\subsection{Limitations and Suggestions for Future Research}

In order to pave the way for further research, it is important for the authors to mention some limitations of this study and make suggestions for further research. As the current study explores the relationship between customer experience and consumer switching behavior, the research model can be extended by including other factors independent from customer experience such as switching costs which are also found to be affective on the consumer switching behavior. This will provide a more holistic understanding of the underlying relationships within the constructs employed in the model. Secondly, crosscountry differences, and generational comparison may be included in the future studies to reach at more generalizable results.

\section{References}

Aaker D. (1991). Managing Brand Equity: Capitalizing on the Value of a Brand Name, The Free Press, New York, NY.

Ajzen, I. \& Driver, B.L. (1992). Contingent value measurement: On the nature and meaning of willingness to pay. Journal of Consumer Psychology, 1, 297-316.

Akgün, A. e., Ince, H., Imamoğlu, S., Keskin, H., \& Kocoğlu, I. (2014). The mediator role of learning capability and business innovativeness between total quality management and financial performance. International Journal of Production Research, 52(3), 888901.

Al-Msallam, S. (2015). Customer Satisfaction and Brand Loyalty in the Hotel Industry. European Scientific Journal, 1(October 2015 Special Edition), 232-251.

Anderson, James C., Gerbing, David W. (1988). Structural equation modeling in practice: A review and recommended two-step approach Psychological Bulletin, Vol 103(3), May 1988, 411-423.

Anderson, E. W., Fornell, C. \& Lehmann, D.R. (1994), "Customer Satisfaction, Market Share, and Profitability," Journal of Marketing, 56 (July), 53-66.

Anderson, E. W. (1996). Customer Satisfaction and Price Tolerance. Marketing Letters, 7 (3), 265-274.

Anderson, R. \& Srinivasan, K. (2003). E-Satisfaction and E-Loyalty: A Contingency Framework. Psychology and Marketing, 20(2), 123-138.

Anderson, E.W., Fornell, C. \& Mazvancheryl, S.K. (2004). Customer Satisfaction and Shareholder Value. Journal of Marketing 68 (October 2004), 172-185.

Antón, C., Camarero, C. \& Carrero, M. (2007). Analyzing firms' failures as determinants of consumer switching intentions: The effect of moderating factors. European Journal of Marketing, 41(1/2), 135-158. 
Awan, A.G. \& Rehman, A. (2014). Impact of customer satisfaction on brand loyalty: An empirical analysis of home appliances in Pakistan. British Journal of Marketing Studies, 2(8), 18-32.

Bagozzi, R. P., \& Yi, Y. (1990). Assessing Method Variance in Multitrait-Multimethod Matrices: The Case of Self-Reported Affect and Perceptions at Work. Journal of Applied Psychology, 75(1), 547-560.

Bansal, H. S. and Taylor, S. F. (2002), Investigating interactive effects in the theory of planned behavior in a service provider switching context. Psychology \& Marketing, 19: 407-425

Baldinger, A.L. \& Rubinson, J. (1996). Brand loyalty: The link between attitude and behavior. Journal of Advertising Research, 36(Nov-December), 22-34.

Bansal, H.S., Taylor, S.F. and James, Y.S. (2005). Migrating to new service providers: toward a unifying framework of consumers' switching behaviour. Journal of the Academy of Marketing Science, 33(1), 96-115.

Başer, İ. U., Cintamür, I.G., \& Arslan F.M. (2015). Examining the effect of brand experience on consumer satisfaction, brand trust and brand loyalty, Marmara Üniversitesi İİB Fakültesi Dergisi, 37(2), 101-128.

Biedenbach, G. \& Marell, A. (2010). The impact of customer experience on brand equity in a business-to-business services setting. Journal of Brand Management, 17(6), 446458.

Blattberg, R.C \& Sen, S.K. (1974). Market Segmentation Using Models of Multidimensional Purchasing Behavior. Journal of Marketing, 38(4), 17-28.

Bloemer, J. \&De Ruyter, K. (1998). On the relationship between store image, store satisfaction and store loyalty. European Journal of Marketing, 32(5/6), 499-513.

Boulding, W. (1990). Commentary on unobservable effects and business performance: Do fixed effects really matter? Marketing Science, 9(Winter), 88-91.

Brakus, J.J., Schmitt, B.H.H. and Zhang, S. (2008). Experiential attributes and consumer judgment. in Schmitt, B.H. and Rogers, D.L. (Eds.), Handbook on Brand and Experience Management, Cheltenham, UK, Edward Elgar, 2008, 174-187.

Burnham, T.A., Frels, J.K., \& Mahajan, V. (2003). Consumer switching costs: A typology, antecedents, and consequences. Academy of Marketing Science, 31(2), 109-126.

Byrne, B. M. (2010). Structural Equation Modeling with AMOS. New York: Routledge Taylor \& Francis Group.

Carbone, L. P. \& Haeckel, S.H. (1994), Engineering Customer Experiences. Marketing Management, 3 (3), 9-11.

Chaudhuri, A \& Holbrook, M.B. (2001). The chain of effects from brand trust and brand affect to brand performance: the role of brand loyalty. Journal of Marketing, 65(April), 81-93.

Chi, C.G \& Gursoy, D. (2009). Employee satisfaction, customer satisfaction, and financial performance: An empirical examination. International Journal of Hospitality Management 28 (2009) 245-253. 
Chumpitaz Cáceres, R. \& Paparoidamis, N. (2007). Service Quality, Relationship Satisfaction, Trust, Commitment and Business-to-business Loyalty. European Journal of Marketing, 41(7/8), 836-867.

Civelek, M. E. (2018). Yapısal Eşitliklik Modellemesi Metodolojisi. İstanbul: Beta.

De Keyser, A., Lemon, K.N., Keiningham, T. \& Klaus, P. (2015). A Framework for Understanding and Managing the Customer Experience. MSI Working Paper No. 15121. Cambridge, MA: Marketing Science Institute.

Delgado Ballester, E. \& Munuera Alemán, J.L. (2001). Brand trust in the context of consumer loyalty. European Journal of Marketing, 35(11/12), 1238-1258.

Delgado, E., Munuera, J.L. \& Yagu, M.J. (2003). Development and validation of a brand trust scale. International Journal of Market Research, 45(1), 35-54.

Delgado-Ballester, E. \& Munuera-Aleman, J.L. (2005). Does brand trust matter to brand equity? Journal of Product and Brand Management, 14(3), 187-196.

Dick, A. \& Basu, K. (1994). Customer Loyalty: Toward an Integrated Conceptual Framework. Journal of The Academy of Marketing Science, 22(2), 99-113.

Dodds, W. B., Monroe, K. B., \& Grewal, D. (1991). Effect of price, brand and store information on buyers' product evaluations. Journal of Marketing Research, 28(3), 307-319.

Doney, P.M. \& Cannon, J.P. (1997). An Examination of the Nature of Trust in Buyer-Seller Relationships. Journal of Marketing, 61(April), 35-51.

Fornell, C., \& Larcker, D. (1981). Evaluating Structural Equation Models with Unobservable Variables and Measurement Error. Journal of Marketing Research, 18(1), 39-50.

Fornell, C. (1992). A national customer satisfaction barometer: The Swedish experience. Journal of Marketing, 55 (January), 1-21.

Gamble, A., Juliusson, E.A. \& Gärling, T. (2009). Consumer attitudes towards switching supplier in three deregulated markets. The Journal of Socio-Economics, 38, 814-819.

Ganesan, S. (1994). Determinants of long-term orientation in buyer-seller relationships. Journal of Marketing, 58(April), 1-19.

Grewal, D., Levy, M. \& Kumar, V. (2009). Customer Experience Management in Retailing: An Organizing Framework. Journal of Retailing, 85 (1), 1-14.

Guerrero, L., Colomer, Y., Guàrdia, M. D., Xicola, J. \& Clotet, R. (2000). Consumer attitude towards store brands. Food Quality and Preference, 11(5), 387-395.

Ha, H.Y. and Perks, H. (2005). Effects of consumer perceptions of brand experience on the web: brand familiarity, satisfaction and brand trust. Journal of Consumer Behaviour, 4(6), 2005, 438-452.

Ha, S. and Stoel, L. (2009). Consumer E-Shopping Acceptance: Antecedents in a Technology Acceptance Model. Journal of Business Research, 62(5), 565-571.

Hallowell, R. (1996). The relationship of customer satisfaction, customer loyalty, and profitability: an empirical study. International Journal of Service Industry Management, 7(4), 27-42. 
Harris, L. \& Goode, M. (2004). The Four Levels of Loyalty and the Pivotal Role of Trust: A Study of Online Service Dynamics. Journal of Retailing, 80, 139-158.

Herbig, P., \& Milewicz, J. (1993). The relationship of reputation and credibility to brand success. Journal of Consumer Marketing, 10(3), 18-24.

Heskett, J.L., Sasser, W.E. \& Schlesinger, L.A. (1997). The Service Profit Chain. New York: Free Press.

Hosseini, F. \& Amini, M. (2016). The Effect of Organizational Commitment on Customer Satisfaction with the Mediating Role of Professional Commitment in Tehran Agricultural Bank. Pacific Business Review International, 9(6), 134-141.

Huber, F. Herrmann, A. \& Wricke, M. (2001). Customer satisfaction as an antecedent of price acceptance: results of an empirical study. Journal of Product \& Brand Management, 10(3), 160-169.

Ajzen I. \& Fishbein, M. (2000). Attitudes and the Attitude-Behavior Relation: Reasoned and Automatic Processes. European Review of Social Psychology, 11(1), 1-33.

Iglesias, O. \& Jatinder, J.S. \& Batista-Foguet, J.M. (2011). The role of brand experience and affective commitment in determining brand loyalty. Journal of Brand Management, 18(8), 570-582.

Jacoby, J. \& Kyner, D. B. (1973). Brand Loyalty Vs. Repeat Purchasing Behavior. Journal of Marketing Research (JMR). 10(1), 1-9.

Janda, S. \& Ybarra, A. (2005). Do Product and Consumer Characteristics Affect the Relationship Between Online Experience and Customer Satisfaction? Journal of Internet Commerce, 4(4), 133-151.

Johnson, M. D. and Fornell, C. (1991). A Framework for Comparing Customer Satisfaction Across Individuals and Product Categories. Journal of Economic Psychology, 12 (2), 267-86.

Kanwal, A. \& Lodhi, S. (2015). Relationship between Brand Switching Behaviour \& Customer Satisfaction: A Case of Cosmetic Industry of Karachi. The International Journal Of Business \& Management, Vol 3(11), 49-56.

Keaveney, S.M. (1995). Customer switching behavior in service industries: an exploratory

Study. Journal of Marketing, 59(2), 71-82.

Keiningham, T. L., Munn, T. P. \& Evans, H. (2003). The Impact of Customer Satisfaction on Share of Wallet in a Business-to-Business Environment. Journal of Service Research, 6 (1), 37-50.

Khalifa, M. \& Liu, V. (2007). Online consumer retention: Contingent effects of online shopping habit and online shopping experience. European Journal of Information Systems, 16, 780-792.

Kim, H.S. (2005). Consumer profiles of apparel product involvement and values. Journal of Fashion Marketing and Management: An International Journal, 9(2), 207-220.

Kim, D.J., Ferrin, D.L. \& Rao, H.R. (2008). A trust based consumer decision making model in electronic commerce: The role of trust, perceived risk, and their antecedents. Decision Support Systems, 44(2), 544-564. 
Lam, Y., Shun \& Shankar, V., Erramilli, K. \& Bvsan, M. (2004). Customer Value, Satisfaction, Loyalty, and Switching Costs: An Illustration from a Business-toBusiness Service Context. Journal of The Academy of Marketing Science, 32, 293311.

Lemon, K.N. \& Verhoef, P. C. (2016). Understanding Customer Experience Throughout the Customer Journey. Journal of Marketing, 80(Nov 2016), 69-96.

Lewis, R.B. \& Sourelli, M. (2006). The antecedents of consumer loyalty in retail banking. Journal of Consumer Behaviour, 5(1), 15-31.

Lubis, A.T., Karina, C. \& Palibutan, A. (2015). The impact of contextual factors, brand loyalty and brand switching on purchase decisions of mineral mineral water in convenience store. Journal of Business Strategy and Execution, 8(1), 1-24.

Luo, X. \& Homburg, C. Neglected Outcomes of Customer Satisfaction. Journal of Marketing, 71 (April 2007), 133-149.

Maklan, S. \& Klaus, P.P. (2011). Customer Experience: Are we measuring the right things? International Journal of Market Research, 53(6), 771-793.

McAlexander, J., Kim, S. \& Roberts, S. (2003). Loyalty: The Influences of Satisfaction and Brand Community Integration. The Journal of Marketing Theory and Practice, 11(4), $1-11$.

Mellens, M., Dekimpe, M.G., \& Steenkamp, J.-B. E. M. (1996). A review of brand loyalty measures in marketing. Tijdschrift voor Economie en Management, 41(4), 507-533.

Meydan, C. H. and Şeşen, H. (2011). Yapısal Eşitlik Modellemesi AMOS Uygulamaları. Detay Yayınc1lik.

Michalski, S. (2004). Types of customer relationship ending processes. Journal of Marketing

Management, 20(9/10), 977-999.

Mittal, V. \& Kamakura, W. (2001). Satisfaction, Repurchase Intent, and Repurchase Behavior: Investigating the Moderating Effect of Customer Characteristics. Journal of Marketing Research, 38 (February), 131-42.

Morgan, R.M. \& Hunt, S. (1994). The commitment-trust theory of relationship marketing. Journal of Marketing, 58(July), 20-38.

Oliver, R.L. (1977). Effects of expectations and disconfirmation on post exposure product evaluations. Journal of Applied Psychology, 62(April), 246-50.

Oliver, R.L. (1980). A cognitive model of the antecedents and consequences of satisfaction decisions. Journal of Marketing Research, 17(4), 460-469.

Oliver, R. L. \& Swan, J. E. (1989). Consumer perceptions of interpersonal equity and satisfaction in transactions: A field survey approach. Journal of Marketing, 53, 21-35.

Pine, B.J. \& Gilmore, J.H. (1998). Welcome to the experience economy. Harvard Business Review, July-August 1998, 97-105.

Power, J., Whelan, S. \& Davies, G. (2008). The attractiveness and connectedness of ruthless brands: the role of trust. European Journal of Marketing, 42(5/6), 586-602. 
Ravald, A. \& Grönroos, C. (1996). The value concept and relationship marketing. European Journal of Marketing, 30(2), 19-30.

Reast, J.D. (2005). Brand trust and brand extension acceptance: the relationship. Journal of Product \& Brand Management, 14(1), 4-13.

Reichheld, F.F. \& Sasser, W.E. (1990). Zero defections: Quality comes to services. Harvard Business Review, 68(September/October), 105-111.

Reichheld, F. \& Kenny, D.W. (1990). The Hidden Advantages of Customer Retention. Journal of Retail Banking, 12(4), 19-23.

Reichheld, F.F. (1996). The Loyalty Effect: The Hidden Force Behind Growth, Profits, and Lasting Value. Boston: Bain \& Company, Inc., 1996.

Rego, L.L., Morgan, N.A. \& Fornell, C. (2013). Reexamining the Market Share-Customer Satisfaction Relationship. Journal of Marketing 1 Vol. 77 (September 2013), 1- 20.

Ribbink, D. \& Van Riel, A., Liljander, V. \& Streukens, S. (2004). Comfort your online customer: Quality, trust and loyalty on the internet. Managing Service Quality, 14(6). 446-456.

Rose, S. Moria, C, Samouel, P., Hair, N. (2012). Online Customer Experience in eRetailing: An empirical model of Antecedents and Outcomes. Journal of Retailing, 88(2), 308-322.

Rust, R.T, Moorman, C. \& Dickson, P.R. (2002). Getting returns from service quality: Revenue expansion, cost reduction or both. Journal of Marketing, 66 (October), 7-24.

Sambandam, R. \& Kenneth, L (1995). Switching Behavior in Automobile Markets: A Consideration-Sets Model. Journal of the Academy of Marketing Science, 23(Winter), 57-65.

Schlesinger (2009), "Customer Experience Creation: Determinants, Dynamics, and Management Strategies," Journal of Retailing, 85 (1), 31-41.

Schmitt, Bernd H. (1999), Experiential Marketing. New York: The Free Press.

Shukla, P. (2004). Effect of product usage, satisfaction and involvement on brand switching behaviour. Asia Pacific Journal of Marketing and Logistics, 16(4), 82-104.

Söderlund, M. (1998). Customer satisfaction and its consequences on customer behaviour revisited: The impact of different levels of satisfaction on word-of-mouth, feedback to the supplier and loyalty. International Journal of Service Industry Management, 9(2), 169-188.

Szymanski, D. M. \& Henard, D.H. (2001). Customer Satisfaction: A Meta-Analysis of the Empirical Evidence. Journal of the Academy of Marketing Science, 29 (1), 16-35.

Şahin, A., Zehir, C. \& Kitapçı, H. (2011). The effects of brand experience, trust, and satisfaction on building brand loyalty. Procedia Social and Behavioral Sciences, 24 (2011), 1288-1301.

Venkat, R. (2007). Impact of Customer Experience on Satisfaction, Brand Image and Loyalty: A Study in a Business-to-Business Context. ASAC (2007), 101-114. 
Verhoef, Peter C., A. Parasuraman, Anne Roggeveen, Michael Tsiros, and Leonard A. (2009). Customer Experience Creation: Determinants, Dynamics and Management Strategies. Journal of Retailing, Vol. 85(1), March 2009, Pages 31-41.

Wang, Y. \& Emurian, H. (2005). An Overview of Online Trust: Concepts, Elements, and Implications. Computers in Human Behavior, 21, 105-125.

Yoo, B. and Donthu, N. (2001). Developing and validating a multidimensional consumerbased brand equity scale. Journal of Business Research, 52(1), 1-14.

Zboja, J.J. \& Voorhees, C.M. (2006). The impact of brand trust and satisfaction on retailer repurchase intentions. Journal of Services Marketing, 20(5), 381-390.

Zeithaml, V. A., Berry, L. L. \& Parasuraman, A. (1996). The behavioral consequences of service quality. Journal of Marketing, 60, 31-46.

Zhou, Z., Zhang, Q., Su, C. \& Zhou, N. (2012). How do brand communities generate brand relationships? Intermediate mechanisms. Journal of Business Research, 65(7), 890895. 